\title{
SUNDANESE AESTHETICS IN DARSO'S VIDEO CLIP DULANG KURING 2
}

\author{
Lingga Agung ${ }^{1}$ Moh Isa Pramana Koesoemadinata ${ }^{2}$ \\ Visual Communication Department \\ Faculty of Creative Industry - Telkom University \\ E-mail:linggaagung@telkomuniversity.ac.id ${ }^{1}$ \\ dronacarya@yahoo.co.id ${ }^{2}$
}

\begin{abstract}
This paper aims to see how the aesthetics in the video clip DulangKuring 2 which was popularized by Alm. Darso. We used qualitative method as a method in collecting related data and to analyze video clip DulangKuring 2, we use Homi K. Bhabha Post-Coloniam theory about mimicry, hybridity, and "the third space". The analysis focuses on Darso, the location (landscape), and the setting-property in the video clip. From the analysis that has been done, the aesthetics in the music video clip DulangKuring 2 is paradoxical because it mixes the local and global aesthetic codes. While through the Bhabha postcolonial, we find that the place (landscape), and setting-property gradually mimicry then after that we'll see another step which is a hybridity that produces "the third space". From the analysis, the video clip DulangKuring 2 is aesthetically very paradoxical yet hybrid because it targets the contemporary Sundanese society.

Keywords: Aesthetic, Communication, Darso, Post-colonialism
\end{abstract}




\section{INTRODUCTION}

Nowadays, art does not only talk about beauty and it does not have to be always in an art. In general, aesthetics is one branch of philosophy that examines the beauty. But it always examine not only the philosophical issues of an art work, but also the social, political, religious, cultural, and even trivial realities. Chernyshevsky, for example, a prominent aesthetist once stated that beauty is life (Suryajaya, 2016). For him, life is a representation of beauty.

The beauty rests on reality so life is the realization of the human concept of the beauty. Thus, we can draw a kind of initial conclusion that a work of art is not necessarily beauty, and beauty is not necessarily a work of art. Similarly, the aesthetically un-sertamerta becomes a work of art and a work of art is not necessarily aesthetic. To be able to determine whether or not aesthetics or a work of art needs basic aesthetic scholarship that will be discussed in the next discussion. Looking at the various definitions above we can understand how aesthetics as a science becomes so dynamic with various opinions and arguments. Aesthetics as a science today is not only related to beauty but also social problems, politics, economy, culture, religion, ideology, morality, and so forth (Agung, 2017)

Sundanese people as one of the people who have a dynamic culture and a dynamic aesthetic realization. Prof. JakobSumardjo (2010) states that the aesthetics of Sundanese is a paradoxical aesthetic that formed from the reality of "Three Pattern Culture". Culture with the three pattern always provides "intermediate space" that brings the differences in it. In the "intermediate space" each of these differences is not mutually negated but mutually alive and creates something that is not original but it's authentics.

For examples, the wayang golek purwa combines very contradictory things like the sophisticated/order aesthetic values (literary and musical arts) and a very rough/chaotic (sarcastic sarcas of the panakawan). The paradox created from the two opposite things are unified, the art of wayang golek purwa is very demanded by the Sundanese people.

Wayang golek purwa thus is the realiation of the Sundanese people of beauty in which there are values that realize the Sundanese society in general the pundungan (which is represented by the aesthetic values are smooth) and the heureuy(represented by the aesthetic values are "rough "Like the Panakawan's hoax). From this explanation, the arts of wayang golek purwa is a revealing medium that validates and communicates the realizations of the beauty of Sundanese society.

Therefore, the art of wayang golek purwa is an aesthetic form that communicates the message in symbolic ways. Besides the arts of wayang golek purwa, Sundanese people generally like music. One of them is Sundanese pop music developed around the 60s. Pop sunda itself is an amalgamation of karawitan art with Western music:

"In the 1960s and 1970s, most arrangers, including Mohammad Jassin, ZaenalArifien, Muslihat, Mus K. Wirya, KosamanDjaja, IndraRivai, SjaifulBachri and Jack Lemmers accompanied Sundanese songs using a Western diatonic scale and functional harmony. Ridwan, 2014)."

Pop Sundanese has grown so significanly especially since the $90 \mathrm{~s}$ with the emergence of video clips from the artists. Video clips then have a very important 
role, especially for the artists to show their existence.

Video clips have aesthetic values as well because they convey something symbolically because the music itself is one of the earliest art forms. In some video clips of pop sunda we can see how the realizations of the Sundanese society are represented. However, such representations do not seem to escape the various constructions of reality that have been constructed as well. The construct representation in the video clips of the sunda pop is the result of a tough negotiation between past cultures and the present culture; with local ones or global ones.

Therefore, the aesthetic value in it becomes very complex. For example we can see on some video clips Darso. Darso, the legends and patron saint pop sunda who had passed away in 2011 ago in some of his video clips always show something unique and aesthetically very absurd but if we noticed it is so complex and very confusing. Apart from the style of clothing that "nyeleneh" from head to toe. Darso is a skinny person also has a very delayed facial profile.

Some of his video clips are conceptually very uncomfortable even impressed as made just like that. There will be some characteristics that always stick in the video clip: we can always see the beautiful garden, Western-style grand building, the dancers dressed in a modern style and traditional dress, with choreography that looks so random. Visually, some of Darso's video clips are far from aesthetic impression. But for the researchers, there is something else beyond the conventional aesthetic values. Darso's video clips can be seen as an aesthetic realization that represents the current Sundanese society. Darso's clip videos, Dulang Kuring 2 (2011) have the most noticeable complexity because it contains something in postcolonial terms called mimicry, hybrid, and third space.

By studying it through postcolonial approach, the researcher hopes that the results obtained will not only show her aesthetic values but also show cultural relation especially how the video clip as a form of symbolic communication resulting from construction of reality of Sundanese society at this time.

\section{RESEARCH METHOD}

This study used qualitative research methods. Basrowi and Suwandi define qualitative research as a research that departs from naturalistic inquiry of which findings are not obtained from statistical calculation procedures. It explorates information resources thoroughly to obtain factual research results-in accordance with the actual situation (2008). In other words, this research begins by collecting primary and secondary data. Primary data is video Clip DulangKuring 2 (2011) popularized by Darso while secondary data is literature study from various related literature. While to analyze the video clip we use the theory of Homi K. Bhabhaposkolonialisme. The term Poskolonial comes from two words namely post (after) and colonial (colonies) which can be interpreted as "after colonial times" or conditions after colonial times. The condition after the colonial period is like a system or cultural elements brought by colonialists who then imitated and used by the former colonies as a new cultural element (Lubis, 2015).

Poskolonial examines the impact of colonialism and its influence on a nation that is colonized socially, culturally, politically, economically, art, and others. Edward Said, Gayatri C. 
Spivak, and Homi K. Bhabha are The Holy Trinity in postcolonial studies. Edward Said highlights the problem of Western domination and manipulation of science and ideology that are used as a tool to continue colonizing. Spivak always talks about marginalized groups of society, marginal people who are often forgotten and deliberately forgotten. Spivak calls it the term subaltern. (Lubis, 2015). While Homi K. Bhabha highlights the "third space" formed as a result of negotiations between colonial cultures and colonized cultures. It is in this "third space", Bhabha, explains the issue of dual identity which was born as a result of the construction of subjects between the colonized and the colonized or vice versa. Bhabha explains the question of the dual identity that was born as a result of the construction of a subject between the colonized and the colonized or vice versa.

Homi K. Bhabha gave birth to two ideas in postcolonial studies, namely mimicry and hybrids. Mimicry is a subject of a difference that is almost the same, but not quite (Bhabha, 1994). Mimicry not only imitates colonial culture but also the economic system, law, politics, art, education, lifestyle, way of thinking, and how to dress. Mimicry is a sign of double articulation, complex renewal, regulatory, and disciplinary strategy "which is 'appropriates' the other as it visualizes power" (Bhabha, 1994). In addition, Bhabha's most important notion of mimicry is that mimicry is a strategy against the dominant invaders called hybridity. Hybridity is a colonized mixing with the colonized both socially, culturally, politically, economically, and including identity. Bhabha argues that hybridity is a strategic reversal of the process of domination through insubordination (ie, the production of discriminatory identities that is secure the original and "pure" identity of the ruling) (Bhabha, 1995).

Hybridity is a threat to the status quo because it can undermine the boundaries between the colonized and the colonized. Hybridity in the colonial environment can serve as a means of defining a new field free of orthodoxy from the colonial regime and the nationalist identities that must replace it. Hybridity, for example, can be seen in the adoption of cultural forms such as clothing, food, and so on.

However, hybridity draws not only attention to the products of cultural fusion itself, but also the way in which these cultural products are placed in social and historical space under colonialism becomes part of the imposition of rejection of colonial power relations (Young, 1995). In the context of this research, hybridity is more a strategy to counter the domination of the invaders through mixing cultural codes. In this study, the analysis will be focused on Darso, the place (location/landscape), and the setting-property in the video clip Dulang Kuring 2.

\subsection{RESULTS AND DISCUSSION}

The music video clip Dulang Kuring 2 was created by Dose Hudaya, produced by $\mathrm{DH}$ Production in 2011. Kuring 2 told about a man left behind by his wife and the man begged his wife to return. The analysis of Dulang Kuring 2 music video clip used Homi K. Bhabha poscolonial theory about mimicry, hybridity, and third space. 


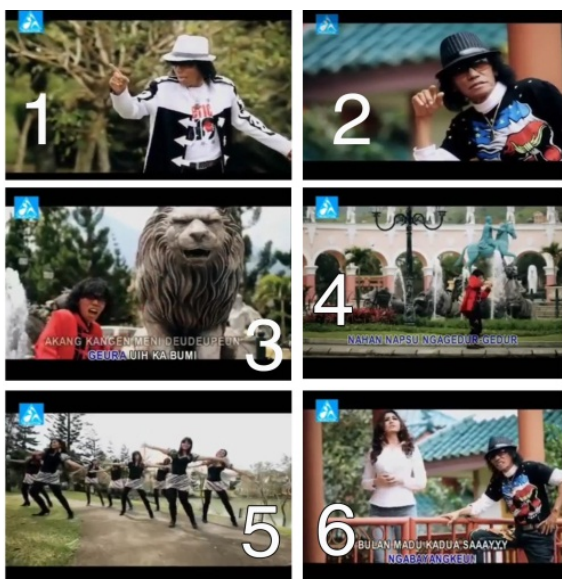

Picture 1 Dulang Kuring 2, Darso (2011). Taken from

https://www.youtube.com/watch?v=63R1yAjLc zo, 2016.

Based on the observation made by researchers, some people called Darso as "The King of Sundanese Pop" for his relentless efforts in the Sundanese pop scene. Although, at the beginning of his career, Darso had labeled as a destroyer of Sundanese pop because he looked strange and weird, even many peopel thought that he was plebeian. Because of the hard work, Darso with all his uniqueness increasingly recognized, even received several prestigious awards such as, Anugerah Jabar Music Award (2005) and Cultural Heritage Bandung (2009). Padjajaran University appreciated Darso by holding a solo concert for him at the end of 2009 entitled "The Phenomenon."

In Picture 1 we can see how Darso looks with his signature move: "ngibing" like jaipong but he moved incoherently with occasional sticking out his tongue. This signature move was on the development imitated by other Sundanese male singers such as Yayan Jatnika, Asep Darso, Kunkun, and even Sule. Later still in the same picture, we can see Darso dressed like
Michael Jackson (Next will be called MJ) "The King of Pop" complete with his fedora hat.

In Picture 2, Darso used overlapping clothing such as the 80s hiphop artist with the brown glasses and a black fedora hat. The two images showed that Darso did the mimicry: imitating MJ and a westernized fashion. However, the imitation was not totally totalistic because it bumped with its localization. It means that the imitation is not a kind of plagiarism because it creates something new that is formed from both things. It is at this stage that mimicry becomes a kind of parody and Darso in this case may be resistant to Western culture.

Picture 3 is about Darso and lion statue, picture 4 is about Darso drawings and a co-opched (landscape) between West and East (large buildings such as monuments and horse statues with riders), and a picture 5 descries modern-dressed background dancers with a touch of batik housed in beautiful nature. In Pictures 3 and 4 the presence of Darso becomes a representation that affirms loyalty to the local culture as well as the picture of 5 dancers with batik motifs on the clothing. Sundanese aesthetics oriented to the beauty of nature in the real sense, one of them is the realization of Sundanese aesthetics in Dancing Kuring 2.

Video Clip Dulang Kuring 2 seeks to locate local culture (Sundanese culture) with global (Western) culture on parallel level. For example, the selection of dancers was divided into two groups: jaipong and modern dances-or it combined the two dances. The selection of locations combined beautiful natural landscapes 
(mountains, hills, rice fields, gardens, beaches and parks) and modern western landscapes (luxurious, majestic homes, monuments such as horse statues, lions, and pillars a GrecoRoman). The three things were formed space hybridity because it was constructed from local elements as well as Western elements. Darso, beautiful nature, and batik motif were representations of localization (Sundanese aesthetics) in the Western landscape. Inside the postcolonial discourse the place is not merely referring to the landscape but rather to the process in which space is attached to meaning, which is directly related to the subject (Aschroft 1995). Place becomes a discursive practice in which the easiest feeling of alienation can be found (Aschroft, 2002).

Picture 6 Darso was wooing his wife home. His wife was very attractive with a sweet face and a sexy body, long brown hair, and a white shirt with tight jeans. We can see how the concept of female beauty is represented in the Western style with the distinctive characteristics of the Priangan girl. This is actually a hybrid representation that can be studied further in feminism view.

Figures 1, 2, 3, 4, 5, and 6 showed how mimicry becomes hybridity and how hybridity becomes "third space": which articulates locality with the West into a relatively newer form of identity. Therefore, the music of video clip Dulang Kuring 2 in postcolonial discourse could be a kind of cultural resistance and even a strategy against Western cultural domination. The clip video of Kuring 2 showed mimicry, hybridity, and the formation of a "third space" through mimicry performed by
Darso, the hybridity was formed by it, and the third space which became a dynamic symbolic battleground because it could be reinterpreted. Video clip Dulang Kuring 2 could also be seen as a form of mockery (mockery) against Western culture which in this case is not able to fully penetrate into the local culture totally. Because the video clip Dulang Kuring 2 shows a kind of dual identity paradox in accordance with the concept of aesthetics and culture of the Sundanese paradox because the values of beauty were mixed with one another without negating one and the other.

\section{CONCLUSION}

From the analysis that has been done, it can be seen that Darso's aesthetic in video clip Dulang Kuring 2 realized the concept of Sundanese aesthetics contemporary in which there is paradox with the existence of "intermediate space" and "third room". The "intermediate space" and the "third space" are formed through mimicry, hybridity, and the third space is formed by Darso, the place (landscape/space), and the settingproperty in it. Darso played an important role as a Sundanese aesthetic representation as well as dancers and wives. While the place into a discursive space symbolically shows the third space. Video clip Dulang Kuring 2 shows a bit of the paradoxical character of Sundanese society: humorous but it is irritable, easy to accept and tends to imitate and mix things up without any proper reference. Therefore, Mimicry, hybrids, and the "third space" that form the aesthetic style of the video are produced effectivelly and they are 
appropriate form of communication giving the target of contemporary Sundanese society which is basically very paradoxical because on one hand it is highly irritable (pundungan) but there is also found jokes. Video clip Dulang Kuring 2 seems very playful (bodor) when it comes to a very serious thing namely the sustainability of the household concerned: paradoxically aesthetic and effective communication in targeting the contemporary Sundanese people who in reality like that.

\section{BIBLIOGRAPHY}

Agung, Lingga. (2017). Pengantar Sejarah dan Konsep Estetika. Yogyakarta: PT. Kanisius.

Aschroft, B., Griffiths, G., \& Tiffin, H. (1995). The Post-Colonial Studies Reader. New York: Routledge.

Basrowi dan Suwandi. (2008). Penelitian Kualitatif. Jakarta: Rineka Cipta.

Bhabha, Homi. (1994). The Location of Culture. London: Routledge.

Lubis, Yusuf Akhyar. (2015). Pemikiran Kritis Kontemporer Dari Teori Kritis, Culture Studies, Feminisme, Postkolonial, Hingga Multikulturalisme. Jakarta:Rajawali Press.

Ridwan, Indra. (2014). The Art Of The Arranger In Pop Sunda, Sundanese Popular Music Of West Java, Indonesia. (Kenneth P. Dietrich School of Arts and Sciences: University of Pittsburgh.

Sumardjo, Jakob. (2010). Estetika Paradoks. Bandung: Sunan Ambu Press.
Suryajaya, Martin. (2016). Sejarah Estetika: Era Klasik Sampai Kontemporer. Jakarta dan Yogyakarta: Gang Kabeldan Indie Book Corner.

Young, Robert. J. C. (1995). Colonial Desire: Hybridity in Theory, Culture and Race. London: Routledge.

\section{OTHER:}

www.youtube.com: https://www.youtube.com/watch?v=6 3R1yAjLczo, Dulang Kuring 2, 2011 diunduh tanggal 22/06/2017 pukul 2.20 WI 